\title{
Ejecutividad y prescripción de las sanciones administrativas en las Leyes 39/2015, del Procedimiento Administrativo Común de las Administraciones Públicas y 40/2015, de Régimen Jurídico del Sector Público*
}

Carmen Chinchilla Marín

DOI: https://doi.org/10.47623/ivap-rvap.110.2018.1.02

\begin{abstract}
Sumario: I. La ejecutividad de las sanciones en la Ley 39/2015 del Procedimiento Administrativo Común de las Administraciones públicas. 1. $\mathrm{El}$ «no caber recurso administrativo alguno» contra la sanción como condición para que sea ejecutiva. 2. La resolución expresa de los recursos administrativos como condición para que las sanciones adquieran firmeza administrativa y sean ejecutivas. - II. La prescripción de las sanciones en la Ley 40/2015, de Régimen jurídico del Sector público. 1. La regla del cómputo del plazo de prescripción de la sanción en los casos de desestimación por silencio del recurso administrativo y su supuesta aplicación solo al recurso de alzada. 2. La regla del cómputo del plazo de prescripción de la sanción en los casos de desestimación por silencio del recurso administrativo y su compatibilidad con la jurisprudencia del Tribunal Constitucional. - III. La ejecutividad de la sanción una vez que ya es ejecutable y antes de que transcurra el plazo para recurrirla ante la Jurisdicción contencioso-administrativa. 1. La regulación de la suspensión de los actos administrativos en la LPAC y en la LJCA. 2. La jurisprudencia del Tribunal Constitucional y del Tribunal Supremo en materia de ejecutividad y suspensión de los actos administrativos: la tutela cautelar como derecho fundamental.
\end{abstract}

I. La ejecutividad de las sanciones en la Ley 39/2015, del Procedimiento Administrativo Común de las Administraciones públicas

1. El «no caber recurso administrativo alguno» contra la sanción como condición para que sea ejecutiva

Como es sabido, los actos administrativos se presumen válidos (artículo 39.1 LPAC); producen efectos desde la fecha en que se notifican a

\footnotetext{
* Mi agradecimiento a Margarita Beladiez, Miguel Loya y Javier Fernández Rivaya por el tiempo que tan generosamente han dedicado a leer este trabajo y por las observaciones tan acertadas que me han hecho.
} 
los interesados (artículo 39.2 LPAC) y son "inmediatamente ejecutivos» (artículos 38 y 98.1 de la LPAC).

De la regla de la ejecutividad inmediata de los actos administrativos se excluían antes (Ley 30/1992) y se siguen excluyendo ahora (Ley $39 / 2015$ ) las sanciones administrativas, lo cual significa que, a diferencia de lo que ocurre con el resto de los actos administrativos, no basta con que la Administración dicte y notifique una resolución sancionadora para que nazca el deber de cumplirla y la correlativa potestad administrativa para hacerla cumplir(1), sino que es necesario que la sanción ponga fin a la vía administrativa, como decía el hoy ya derogado artículo 138.3 de la LRJPAC.

La expresión "poner fin a la vía administrativa" no es la más correcta para determinar el momento a partir del cual son ejecutivas las sanciones, ya que, de acuerdo con la ley, ponen fin a la vía administrativa - entre otras - las resoluciones dictadas por los órganos administrativos que carezcan de superior jerárquico (artículo 114.1 LPAC) (2). Estas resoluciones, al poner fin a la vía administrativa, pueden ser recurridas directamente ante la jurisdicción contencioso-administrativa, o, si se quiere, puesto que se trata de un recurso potestativo, en reposición ante el mismo órgano que las ha dictado. Por el contrario, las resoluciones dictadas por órganos que tienen un superior jerárquico no pueden ser recurridas directamente ante los Tribunales, sino que, previamente, deben ser recurridas en alzada y, una vez resuelto el recurso, podrán someterse al control judicial. Siendo ello así, una interpretación literal de la regla que establece que las sanciones serán ejecutivas "cuando pongan fin a la vía administrativa" Ilevaría a la consecuencia, absurda, de que una sanción recurrible en alzada no sería ejecutiva mientras no se resolviese el recurso de alzada (o hasta que no transcurriese el tiempo para interponerlo y no se interpusiera), y, por el contrario, una sanción impuesta por un órgano administrativo que careciere de superior jerárquico y que, por tanto, no fuera recurrible en alzada, sí sería ejecutiva a pesar de que contra dicha sanción pudiera interponerse recurso potestativo de reposición.

En mi opinión, la interpretación más lógica, aunque no la literal, de la expresión del artículo 138.3 de la ya derogada LRJPAC «poner fin a la vía administrativa" es entender que, en realidad, lo que el precepto quería decir era "adquirir firmeza en vía administrativa", con lo cual las sanciones no serían ejecutivas mientras existiese la posibilidad de interponer

(1) De acuerdo con lo establecido en el artículo 100 de la LPAC, los medios de ejecución forzosa de los actos administrativos son los siguientes: el apremio sobre el patrimonio; la ejecución subsidiaria; la multa coercitiva; y la compulsión directa sobre las personas.

(2) Antes, en el mismo sentido, el artículo 109. a) de la LRJPAC. 
un recurso administrativo, ya fuese de alzada, ya de reposición, o mientras que, habiéndose interpuesto recurso administrativo, este no hubiese sido resuelto. No obstante ser esta la interpretación más lógica de la expresión "poner fin a la vía administrativa», hubo Tribunales de lo contencioso-administrativo que interpretaron el artículo 138.3 de la LRJPAC en su sentido literal y concluyeron que las sanciones recurridas en reposición eran ejecutivas desde el momento mismo en que el órgano administrativo dictaba (y notificaba, claro está) la resolución sancionadora, todo ello sobre la base de entender que, al no haberse modificado por la Ley 4/1999 el artículo 138.3 de la Ley 30/1992, y haberse mantenido, por tanto, la regla según la cual son ejecutivas las sanciones que pongan fin a la vía administrativa, "queda clara la voluntad legislativa de que si se interpone el potestativo recurso de reposición cabe la posibilidad de ejecución inmediata acordada por el órgano administrativo" (3).

Afortunadamente, la nueva ley del Procedimiento Administrativo Común ha venido a poner fin a la confusión creada por el artículo 138.3 de la LRJPAC (4), diciendo ahora, en su artículo 90.3, y en referencia a las resoluciones sancionadoras, que

"La resolución que ponga fin al procedimiento será ejecutiva cuando no quepa contra ella ningún recurso ordinario en vía administrativa...".

Y especificando, a continuación, en su artículo 98.1.b), para que no quepa ya duda alguna, que

"Los actos de las Administraciones públicas sujetos al Derecho Administrativo serán inmediatamente ejecutivos, salvo que $[\ldots]$ se trate de una resolución de un procedimiento de

\footnotetext{
(3) Sentencia del Tribunal Superior de Justicia de Galicia, de 13 de octubre de 2005, número 733/2005, (recurso n. ${ }^{\circ} 545 / 2001$ ).

Frente a esta sentencia, existen otras, de otros Tribunales de Justicia, que mantuvieron la tesis contraria, es decir, que, una vez interpuesto el recurso de reposición, la sanción no es ejecutiva hasta que no se resuelve dicho recurso, por considerar que, hasta ese momento, el acto administrativo sancionador no es firme (Sentencia del Tribunal Superior de Justicia del País Vasco, de 30 de octubre de 1996, número 716/1996, recurso 2682/1995, y otras como las Sentencias del Tribunal Superior de Justicia de Valencia, de 12 de mayo de 2000, número 764/2000, recurso 3050/1996, y del Tribunal Superior de Justicia de Andalucía, de 28 de mayo de 2001, número 372/2001, recurso 144/2001).
}

(4) Sobre la confusión que produjo esta expresión y las distintas expresiones utilizadas por las leyes para definir cuándo se produce la ejecutividad de las sanciones administrativas («poner fin a la vía administrativa», "agotar la vía administrativa» y "ser firme en vía administrativa). Vid. MARTíN REBOLLO, L. (2016), "La potestad sancionadora y la responsabilidad patrimonial: los nuevos "procedimientos comunes especializados" ", en Innovaciones en el procedimiento administrativo común y el régimen jurídico del sector público, LÓPEZ MENUDO, F. (Director), Sevilla, Editorial Universidad de Sevilla, págs. 362-364. 
naturaleza sancionadora contra la que quepa algún recurso en vía administrativa, incluido el potestativo de reposición».

La LPAC no dice, como decía antes la LRJPAC, que las sanciones serán ejecutivas cuando pongan fin a la vía administrativa, pero tampoco dice que lo serán cuando sean firmes en vía administrativa. El legislador, es difícil saber si intencionadamente o no, ha prescindido de esas dos expresiones $y$, en su lugar, ha definido la ejecutividad de las sanciones por referencia a una circunstancia muy concreta: que no quepa contra la sanción recurso administrativo ordinario alguno.

Así, pues, queda claro ahora que las sanciones solo son ejecutivas cuando se dé una de las dos circunstancias siguientes: (i) que transcurran los plazos del recurso administrativo que proceda - alzada o reposiciónsin haberse interpuesto o (ii) que, habiéndose interpuesto el recurso administrativo, dicho recurso haya sido desestimado y, en consecuencia, haya sido confirmada la validez de la sanción impuesta.

En relación con este último aspecto, es decir, la cuestión de la desestimación del recurso administrativo como condición para que las sanciones que hayan sido recurridas adquieran el atributo de la ejecutividad, se plantea la duda de si es necesario, para ello, que el recurso de alzada (ahora ya también, sin duda, el de reposición) haya sido desestimado de forma expresa o si, por el contrario, también es ejecutiva una sanción desde el momento en que el recurso interpuesto contra la misma haya sido desestimado por silencio administrativo. La duda planteada surge de la regulación que las leyes de Procedimiento administrativo - la anterior y la actual - hacen del silencio administrativo $y$, sobre todo, de la interpretación que los tribunales han hecho de esta cuestión cuando estaba en vigor la Ley 30/1992.

\section{La resolución expresa de los recursos administrativos como condición para que las sanciones adquieran firmeza administrativa y sean ejecutivas}

De acuerdo con lo establecido en el artículo 24. 1 de la Ley 39/2015, en sentido idéntico a lo que establecía ya, a este respecto, el artículo 43.1 de la Ley 30/1992, el silencio, en los recursos administrativos, tendrá sentido negativo, lo que significa que el transcurso del plazo máximo para resolver, sin que la Administración haya dictado y notificado su resolución, legitima al recurrente para entender que su recurso ha sido desestimado $y$, por tanto, para interponer el recurso contencioso-administrativo. Ahora bien, dado que el silencio negativo - a diferencia de lo que ocurre con el silencio positivo - no tiene la consideración legal de "acto administrativo 
finalizador del procedimiento" (artículo 24.2 de la LPAC) (5), y dado que la ley lo concibe como una ficción a "los solos efectos de permitir a los interesados la interposición del recurso administrativo o contencioso-administrativo que resulte procedente» (artículo 24.2 de la LPAC) (6), elTribunal Constitucional, en su sentencia 243/2006, ha declarado que es necesario que el recurso de alzada sea desestimado "expresa y totalmente» para que la sanción sea ejecutiva. Es decir, que, según esta sentencia, la desestimación por silencio del recurso de alzada no determina la firmeza de la sanción impugnada y, por lo tanto, no puede ser ejecutiva. Así, pues, de acuerdo con esta jurisprudencia, mientras la Administración no cumpla con su obligación de dictar y notificar la resolución expresa que ponga fin al recurso administrativo interpuesto contra una sanción, dicha sanción no será ejecutiva.

Con posterioridad a esta sentencia delTribunal Constitucional, el Tribunal Supremo, resolviendo un recurso de casación en interés de ley, declaró como doctrina legal la siguiente:

«interpuesto recurso de alzada contra una resolución sancionadora, el transcurso del plazo de tres meses para la resolución del mismo no supone que la sanción gane firmeza ni que se convierta en ejecutiva, de modo que no puede iniciarse el cómputo del plazo de prescripción de la sanción» (7).

El Tribunal Supremo daba, pues, un paso más con esta sentencia, diciendo que la falta de resolución expresa de un recurso de alzada interpuesto contra una sanción impide no solo que la sanción recurrida adquiera firmeza $y$, en consecuencia, sea ejecutiva, sino también que el cómputo del plazo de prescripción de la sanción comience a correr. Esta conclusión es lógica, pues si la prescripción de la sanción supone la imposibilidad de que la Administración ejecute la sanción como consecuencia de haber dejado transcurrir el plazo que la ley establece para ello sin haberla ejecutado, es evidente que, mientras que la sanción no sea ejecutiva, el plazo de prescripción no puede empezar a contar, debido sencillamente a que la ejecutividad de la sanción es el presupuesto que debe darse para que la Administración pueda ejecutarla. 0 , dicho de otro modo: si la Administración no puede ejecutar la sanción, difícilmente puede empezar a correr el plazo que la ley establece para que la ejecute.

(5) En sentido idéntico, el artículo 43.2 de la LRJPAC.

(6) En el mismo sentido, el artículo 43.2 de la LRJPAC.

(7) STS de 22 de septiembre de 2008, recurso de casación en interés de ley n. ${ }^{\circ} 69 / 2005$. Esta misma doctrina ha sido reiterada por el Tribunal Supremo en su Sentencia de 15 de febrero de 2013 (recurso de casación $n .^{\circ} 3378 / 2008$ ). 
Con lo cual, si, según el Tribunal Constitucional, la Administración no puede ejecutar la sanción hasta que no haya resuelto de forma expresa el recurso administrativo interpuesto contra la misma, por entender que solo a partir de ese momento habrá adquirido firmeza, lo lógico es que tampoco pueda comenzar a correr el plazo de prescripción de la sanción, ya que, de conformidad con lo establecido en el artículo 132.3 de la entonces vigente LRJPAC, dicho plazo "comenzará a contarse desde el día siguiente a aquel en que adquiere firmeza la resolución por la que se impone la sanción». Si la resolución no es firme, porque el recurso no se ha resuelto de forma expresa, la sanción tampoco puede prescribir (8).

Así, pues, tanto por el Tribunal Constitucional (STC 243/2006) como por el Tribunal Supremo (Sentencia de 22 de septiembre de 2008, dictada en recurso de casación en interés de ley) la cuestión había quedado fijada en términos muy claros: interpuesto un recurso de alzada contra una sanción, su desestimación por silencio administrativo impide que la sanción adquiera firmeza y, por consiguiente, ni es ejecutiva ni puede empezar a computarse el plazo de prescripción de la misma.

Hasta tal punto coincidían la interpretación del Tribunal Constitucional y del Tribunal Supremo sobre esta cuestión, que, años después, cuando un Juzgado de lo Contencioso planteó una cuestión de inconstitucionalidad sobre determinados preceptos legales (9), así como sobre la interpretación que, con carácter vinculante, había hecho de ellos el Tribunal Supremo en recursos de casación en interés de ley(10), por considerarla contraria a la doctrina del Tribunal Constitucional sobre el silencio admi-

(8) Como diría, con razón, el Abogado del Estado en el recurso de casación resuelto por la Sentencia de 15 de febrero de 2013, en la que expresamente se reitera y mantiene la doctrina legal establecida en la Sentencia de 22 de septiembre de 2008, "no cabe admitir razón alguna para considerar que existe "firmeza" que permite el inicio del cómputo del plazo prescriptivo y otra distinta que dota de ejecutividad a la resolución sancionadora, al contrario, ambas deben correr juntas (en virtud, dice, de la teoría de la "actio nata")". Las alegaciones del Abogado del Estado se recogen en estos términos en el Fundamento de Derecho segundo de la STS de 15 de febrero de 2013.

En el fundamento de Derecho tercero se citan la sentencia de 22 de septiembre de 2008 (dictada en recurso de casación en interés de ley y en la que se fija la doctrina legal que ha quedado transcrita en el texto) y la de 15 de diciembre de 2004, dictada también en recurso de casación en interés de ley, que estableció, como doctrina legal, que "el límite para el ejercicio de la potestad sancionadora, y para la prescripción de las infracciones, concluye con la resolución sancionadora y su consiguiente notificación, sin poder extender la misma a la vía de recurso". A continuación, en el Fundamento de Derecho cuarto, el Tribunal Supremo afirma que «las consideraciones jurídicas expuestas en ambas sentencias, y las conclusiones alcanzadas sobre la base de las mismas, deben ser mantenidas al no apreciarse razones que aconsejen su rectificación".

(9) El art. 81 del Texto articulado de la Ley sobre Tráfico, Circulación de Vehículos a Motor y Seguridad Vial, aprobado por Real Decreto Legislativo 339/1990, de 2 de marzo, y el art. 132 de la Ley 30/1992, de 26 de noviembre, de Régimen Jurídico de las Administraciones Públicas y del Procedimiento Administrativo Común.

(10) Sentencias, dictadas en recurso de casación en interés de ley, de 15 de diciembre de 2004 y 22 de septiembre de 2008, ya citadas. 
nistrativo, el Tribunal Constitucional rechazó el planteamiento del Juzgado afirmando que no se advertía contradicción alguna entre la doctrina legal sentada por el Tribunal Supremo y la doctrina del Tribunal Constitucional, y que, antes bien, con esa doctrina legal el Tribunal Supremo no había hecho otra cosa «que seguir la doctrina establecida en la STC 243/2006 sobre la firmeza y ejecutividad de la resolución sancionadora pendiente de resolución expresa del recurso de alzada, a los efectos de la prescripción de las sanciones» (STC 37/2012)(11).

\section{La prescripción de las sanciones en la Ley 40/2015, de Régimen jurídico del Sector público}

Así estaban las cosas en la jurisprudencia de los tribunales Constitucional y Supremo, cuando llegó el legislador, en 2015, y estableció la siguiente regulación en el artículo 30.3 de la Ley 40/205, de Régimen jurídico del Sector público:

«el plazo de prescripción de las sanciones comenzará a contarse desde el día siguiente a aquel en que sea ejecutable la resolución por la que se impone la sanción o haya transcurrido el plazo para recurrirla.

Interrumpirá la prescripción la iniciación, con conocimiento del interesado, del procedimiento de ejecución, volviendo a transcurrir el plazo si aquél está paralizado durante más de un mes por causa no imputable al infractor.

En el caso de desestimación presunta del recurso de alzada interpuesto contra la resolución por la que se impone la sanción, el plazo de prescripción comenzará a contarse desde el día siguiente a aquel en que finalice el plazo legalmente previsto para la resolución de dicho recurso".

Si, por un lado, el precepto establece que el plazo de prescripción de las sanciones comenzará a contarse «desde el día siguiente a aquel en que sea ejecutable la resolución por la que se impone la sanción»(12) y, por otro, dice que «en el caso de desestimación presunta del recurso de

(11) En el mismo sentido, las SSTC 91, 93 y 98 de 2012

(12) La fórmula utilizada por el precepto es más amplia, pues lo que dice es que el plazo de prescripción de la sanción comenzará al día siguiente a aquel en que sea ejecutable "o haya transcurrido el plazo para recurrirla». Sin embargo, creo que este último inciso no añade nada, ya que, precisamente, una sanción es ejecutiva cuando ya no quepa contra ella ningún recurso en vía administrativa (artículo 90.3 de la LPAC). 
alzada interpuesto contra la resolución por la que se impone la sanción, el plazo de prescripción comenzará a contarse desde el día siguiente a aquel en que finalice el plazo legalmente previsto para la resolución de dicho recurso", ello significa que, también, desde ese momento, la sanción es ejecutiva, ya que, si no lo fuera, no podría comenzar a computarse el plazo de prescripción, pues, de acuerdo con lo dicho en el párrafo primero del artículo 30.3 LRJSP, la condición para que el plazo de prescripción comience a contarse es que la sanción sea ejecutable.

O dicho de otra forma: siendo la ejecutividad la condición necesaria para que empiece a correr el plazo de la prescripción de la sanciones administrativas, si la ley dice ahora que el cómputo del plazo de prescripción, en los casos de desestimación presunta del recurso de alzada, comienza al día siguiente de aquel en el que se haya producido el silencio negativo, ello es así porque, para el legislador, la desestimación presunta del recurso administrativo hace que la sanción sea ejecutable. Si, como dije antes, la prescripción de las sanciones consiste en la extinción de la potestad administrativa para ejecutarlas, como consecuencia del transcurso del plazo legalmente establecido para ello sin haberlas ejecutado, es obvio que para que una sanción prescriba tiene que darse una condición previa: que la sanción sea susceptible de ser ejecutada.

Por tanto, interpretado en su conjunto el artículo 30.3 de la LRJSP, habrá que concluir que, de acuerdo con la nueva ley, una sanción es "ejecutable» (i) cuando haya transcurrido el plazo del recurso administrativo que proceda y no se haya interpuesto; (ii) cuando habiéndose interpuesto el recurso administrativo, este haya sido desestimado de forma expresa, y (iii) cuando habiéndose interpuesto el recurso administrativo, este haya sido desestimado de forma presunta, es decir, por silencio administrativo.

Esta conclusión no contradice, en mi opinión, lo dispuesto en los artículos 90.3 y 98.1. b) de la LPAC, pues estos preceptos estarían diciendo lo mismo, pero con otras palabras, ya que el hecho de que no quepa contra la sanción ningún recurso ordinario en vía administrativa, incluido el potestativo de reposición - que es la condición que establecen estos preceptos para que una sanción sea ejecutiva - es la circunstancia que se da en las tres situaciones que antes he enunciado: no cabe recurso administrativo ordinario alguno si han transcurrido los plazos para recurrir y no se ha recurrido; tampoco cabe recurso administrativo ordinario alguno cuando, interpuesto el recurso de alzada (preceptivo) o el de reposición (potestativo), el recurso ha sido desestimado de forma expresa; y, finalmente, tampoco cabe recurso administrativo ordinario alguno cuando el recurso haya sido desestimado por silencio administrativo, pues, en tal caso, cabrá la resolución expresa del recurso, si la Administración cumple con su obligación de dictarla y notificarla, aunque sea tardíamente, pero 
lo que no cabrá ya es interponer un recurso administrativo ordinario, que es la circunstancia que, según estos dos preceptos, tiene que darse para que una sanción sea ejecutiva.

Los preceptos citados no dicen que para que la sanción sea ejecutiva tiene que darse la circunstancia de «que no quepa dictar resolución alguna en vía administrativa» sobre la misma, sino que «no quepa contra ella ningún recurso ordinario en vía administrativa». Y quizás esa sea la razón por la que el legislador no ha hablado de firmeza a la hora de definir la condición o circunstancia que hace que una sanción sea ejecutiva, porque si hubiera dicho que las sanciones para ser ejecutivas tienen que ser firmes en vía administrativa, es claro que, mientras que el recurso administrativo interpuesto contra ellas no se resolviera de forma expresa, no se podría decir que habrían adquirido firmeza, pues podrían ser modificadas o, incluso, anuladas. Por tanto, el hecho de que el legislador, en la nueva ley, no haya utilizado la expresión "firmeza administrativa", al definir la ejecutividad de las sanciones administrativas, podría tener más importancia de la que aparenta.

Por todo lo dicho, no comparto la opinión de Tomás Cano cuando dice que el artículo 30.3 de la LRJSP «debería precisar que lo que corre, en rigor, es el plazo de prescripción de la infracción, no el de la sanción porque este, [...], comienza cuando la sanción sea ejecutable y la desestimación por silencio de un recurso no hace ejecutable la sanción» (13). En mi opinión, ello no es así, en primer lugar, porque el precepto separa en dos apartados diferentes las reglas de la prescripción de la infracción (apartado $2^{\circ}$ ) y las de la sanción (apartado $3 .^{\circ}$ ), por lo que carece de sentido entender que, en el apartado dedicado al régimen de la prescripción de las sanciones, el legislador debería aclarar que lo que prescribe - en caso de silencio negativo en vía de recurso- es la infracción y no la sanción, cuando, precisamente, es al régimen de prescripción de las sanciones a lo que está dedicado el apartado $3 .^{\circ}$, en el que se encuentra la nueva regla del silencio.

Es más, en mi opinión cabría entender que la relación entre los párrafos primero y tercero del artículo 30.3 es una relación de regla general y regla especial, de tal manera que el primero vendría a establecer, como regla general, que el plazo de prescripción de las sanciones comienza a contarse desde el día siguiente a aquel en que las sanciones sean ejecutables y el tercero vendría a especificar, para los casos de desestimación de un recurso por silencio, que el plazo de prescripción comienza a contarse a partir del día siguiente a producirse el silencio, con lo cual el precepto no estaría haciendo otra cosa que concretar el momento (el día si-

(13) T. CANO, "El autismo del legislador: la "nueva" regulación de la potestad sancionadora de la Administración", RAP, 201, 2016, pág. 53. 
guiente al que se produce el silencio) en el que se da la condición (ser ejecutable) para que el plazo de prescripción de las sanciones pueda empezar a computarse. Y ello tendría sentido pues, en mi opinión, y como ya he dicho, la ejecutividad y la prescripción de las sanciones no pueden disociarse, ya que la primera es presupuesto de la segunda, pues solo cuando una sanción es ejecutable puede comenzar a computarse el plazo para su prescripción.

En segundo lugar, no comparto la opinión del autor porque, en mi opinión, cuando la Administración impone una sanción dentro del plazo legalmente establecido para ello, se extingue la posibilidad de que la infracción prescriba, ya que la sanción tiene la consideración legal de acto finalizador del procedimiento, y el hecho de que se interponga un recurso administrativo contra la misma no puede implicar una especie de "reiniciación" de un procedimiento que ya ha finalizado con la correspondiente resolución sancionadora. Este es, por lo demás, el criterio establecido por el Tribunal Supremo, en una doctrina legal que ha sido avalada por el Tribunal Constitucional, de acuerdo con la cual el recurso administrativo no reabre los plazos de prescripción de las infracciones administrativas $y$, antes bien, al contrario, la imposición de la sanción dentro del plazo legalmente establecido para ello marca el punto final de la posibilidad de que una infracción prescriba. Esto es, y dicho sea con las palabras delTribunal Supremo, "el límite para el ejercicio de la potestad sancionadora, y para la prescripción de las infracciones, concluye con la resolución sancionadora y su consiguiente notificación, sin poder extender la misma a la vía de recurso» (14).

\section{La regla del cómputo del plazo de prescripción de la sanción en los casos de desestimación por silencio del recurso administrativo y su supuesta aplicación solo al recurso de alzada}

Sorprende que el artículo 30.3 de la LRJSP solo se refiera al recurso de alzada, pues no puede existir justificación alguna para establecer una regla distinta para el recurso de reposición, una vez que la ley ha aclarado que las sanciones solo son ejecutivas cuando no quepa contra ellas recurso administrativo ordinario alguno, «incluido el potestativo de reposición" (artículos 90.3 y 98.b de la LPAC). Si ahora ya está claro que mien-

(14) STS de 15 de diciembre 2004, número de recurso 97/2002. Dicha doctrina ha sido avalada por el Tribunal Constitucional en sus Sentencias 37/2012, 91/2012, 93/2012 y 98/2012. No obstante, cabe destacar que la Sentencia del Tribunal Supremo citada tiene un voto particular del magistrado Peces Morate, al que se adhiere el magistrado Yagüe Gil, en el que se sostiene que si el procedimiento administrativo «se detiene en vía de recurso por un plazo superior al señalado por la Ley para la prescripción de la infracción», esta habrá prescrito y la Administración no podrá castigar al presunto responsable. 
tras quepa un recurso administrativo, ya sea de alzada o de reposición, la sanción no es ejecutiva, y si, igualmente, se ha establecido que el plazo de prescripción comenzará a contarse desde el día siguiente a la desestimación presunta del recurso, lo cual solo puede ser posible porque la sanción ya es ejecutable (artículo 30.3 de la LRJSP), carece de sentido que el precepto mencione solamente el recurso de alzada.

Existe, en mi opinión, un cierto paralelismo entre este precepto -el artículo 30.3 de la LRJSP - que establece la regla sobre el cómputo del plazo de prescripción en los supuestos de desestimación presunta del recurso, mencionando solamente el de alzada, y el artículo 24.1 de la LPAC, que también se refiere solo al recurso de alzada cuando establece el silencio positivo, como excepción a la regla del silencio negativo que es la que rige, con carácter general, para los recursos administrativos. Recordemos el tenor literal de este precepto:

«El sentido del silencio también será desestimatorio en los procedimientos de impugnación de actos y disposiciones y en los de revisión de oficio iniciados a solicitud de los interesados. No obstante, cuando el recurso de alzada se haya interpuesto contra la desestimación por silencio administrativo de una solicitud por el transcurso del plazo, se entenderá estimado el mismo si, llegado el plazo de resolución, el órgano administrativo competente no dictase y notificase resolución expresa, siempre que no se refiera a las materias enumeradas en el párrafo anterior de este apartado» (15).

El precepto se refiere, pues, solo y exclusivamente, al recurso de alzada, por lo que, de nuevo, es necesario preguntarse si puede existir alguna razón que justifique que el silencio sea positivo (salvo que se trate de las materias enumeradas en el propio artículo) cuando el transcurso del tiempo sin dictar resolución expresa se produzca en un recurso de

\footnotetext{
(15) El último inciso - «siempre que no se refiera a las materias enumeradas en el párrafo anterior de este apartado" - es una novedad introducida por la Ley 39/2015 y el párrafo al que se remite dice lo siguiente: «El silencio tendrá efecto desestimatorio en los procedimientos relativos al ejercicio del derecho de petición, a que se refiere el artículo 29 de la Constitución, aquellos cuya estimación tuviera como consecuencia que se transfieran al solicitante o a terceros facultades relativas al dominio público o al servicio público, impliquen el ejercicio de actividades que puedan dañar al medio ambiente y en los procedimientos de responsabilidad patrimonial de las Administraciones públicas".

No obstante, el Tribunal Supremo, estando en vigor la ley 30/1992, ya había sostenido que, en caso de "doble silencio", el sentido del silencio no podía ser positivo si con ello se transferían al interesado facultades relativas al dominio público o al servicio público (STS de 25 de mayo de 2016, recurso n. ${ }^{\circ}$ 2796/2014). Resulta sorprendente que en esta sentencia no se dedique ni una sola palabra para fundamentar una interpretación que no es la que se deduce del sentido literal del artículo 43.1, último párrafo, de la ley 30/1992.
} 
alzada interpuesto contra un silencio negativo ("la desestimación por silencio de una solicitud»), y que, por el contrario, sea negativo cuando el transcurso del tiempo sin resolver se produzca en un recurso de reposición interpuesto contra un silencio negativo. La razón de ser de la regla del silencio positivo en vía de recurso es solo una: otorgar un beneficio - la estimación de su recurso - a quien, después de haber visto desestimada su solicitud por silencio negativo, tendría que soportar, por segunda vez, otro silencio negativo de la Administración. Siendo ello así, la regla debería aplicarse también al recurso de reposición, ya que, por mucho que este recurso sea potestativo, una vez que se opta por interponerlo, el recurrente tiene el mismo derecho que quien interpone un recurso de alzada a que la Administración cumpla con su deber de dictar y notificar una resolución expresa en plazo (artículo 21 de la LPAC); o, dicho de otra manera: quien interpone un recurso de reposición no merece soportar, solo porque el recurso sea potestativo, dos silencios negativos de la Administración.

Pero lo cierto es que el legislador menciona exclusivamente el recurso de alzada cuando regula el silencio en vía de recurso (artículo 24 de la LPAC), de igual forma que, al establecer la regla del cómputo del plazo de prescripción en los supuestos de desestimación presunta del recurso administrativo interpuesto contra una sanción administrativa, se refiere, únicamente también, al recurso de alzada (artículo 30.3 de la LRJSP). Quizás el tratamiento diferenciado que la ley da, en estos dos supuestos, al recurso de alzada y al de reposición solo responda a un descuido del legislador (16), explicado por el hecho de que estas dos leyes -la 39/2015 y la 40/2015-, en las que se ha desdoblado la Ley 30/1992, mantienen la mayor parte del contenido de la ley de 1992, y es posible que, al mantenerla, también hayan "arrastrado", inadvertidamente, preceptos y formas de concebir las cosas que sólo tuvieron sentido en la redacción originaria de la ley de 1992, cuando se eliminó el recurso de reposición y solo existía, como recurso ordinario, el de alzada(17).

(16) Comparto plenamente la opinión deT. CANO CAMPOS cuando dice que el legislador «presenta, especialmente en estas leyes, déficit de atención" y que "se ha limitado a reproducir (a veces incluso mal) lo que ya había en los textos que incorpora y deroga» («El autismo del legislador...», cit. págs. 27-30).

(17) Incomprensiblemente, para mí, la Ley 4/1999, que modificó la Ley 30/1992 y volvió a introducir el recurso de reposición con carácter facultativo, siguió mencionando exclusivamente el recurso de alzada al establecer la regla del silencio positivo - como excepción al silencio negativo - cuando el objeto del recurso fuese, a su vez, una desestimación por silencio. No obstante, lo que parece claro es que la inclusión de la expresión "alzada» no obedece a ningún descuido, pues se introdujo a través de una enmienda presentada por el Grupo Mixto que se justificó en la necesidad de «adecuar el régimen de recursos al sentido del silencio que establece la regulación propuesta» (BOCG, Senado, Serie II, VI legislatura, n. ${ }^{\circ} 106$, pág. 45). La justificación, en mi opinión, no aclara esta cuestión, pues adecuar el régimen del silencio al régimen de recursos debería haber llevado, en buena lógica, a incluir también al recurso de reposición que, precisamente, se volvía a establecer en esta ley, aunque fuese con carácter potestativo. 
Así, pues, por todo lo dicho, y no obstante el tenor literal del artículo 30.3 de la LRJSP, en mi opinión, la regla del inicio del cómputo del plazo de prescripción de las sanciones recurridas en vía administrativa debería aplicarse tanto al recurso de alzada como al de reposición.

\section{La regla del cómputo del plazo de prescripción de la sanción en los casos de desestimación por silencio del recurso administrativo y su compatibilidad con la jurisprudencia del Tribunal Constitucional}

Aparte del problema de interpretación que plantea el hecho de que el artículo 30.3 de la LRJSP solo se refiera al recurso de alzada cuando establece la regla de que el inicio del cómputo del plazo de prescripción de las sanciones recurridas tiene lugar al día siguiente a aquel en el que se haya producido la desestimación del recurso por silencio, este precepto plantea un segundo problema, cual es el de que dicha regla no solo no está en consonancia con la jurisprudencia del Tribunal Constitucional y del Tribunal Supremo en materia de silencio administrativo, sino que tampoco lo estaría, en principio, con la consideración que la LPAC tiene del silencio negativo, al calificarlo de ficción legal o presunción "a los solos efectos" de permitir al interesado recurrir contra el mismo; una concepción esta de la que, como es sabido, la jurisprudencia ha extraído la regla, finalmente consagrada en la ley, de que no hay plazo para recurrir contra el silencio negativo (artículos 122.1 y 124.1 de la LPAC).

Dejando al margen la jurisprudencia del Tribunal Supremo, y centrando nuestro estudio solamente en la doctrina del Tribunal Constitucional, por ser esta la única que podría, en su caso, suponer un impedimento para que el legislador estableciese la regulación que ha incluido en el artículo 30.3 de la LRJSP(18), creo que, en el supuesto que nos ocupa, la doctrina constitucional sobre el silencio negativo y la ejecutividad de las sanciones, sentada en la STC 243/2006, no impide dicha regulación, y ello por las razones que paso a exponer a continuación.

En primer lugar, porque se trata de una doctrina establecida en interpretación de una legislación que no decía, como por el contrario sí dice ahora, que la desestimación del recurso por silencio determina el inicio del cómputo del plazo de prescripción de la sanción, regla esta que, por la razones que ya he expuesto, lleva consigo, también, que a partir de ese momento la sanción sea ejecutiva.

(18) Sobre la cuestión de la vinculación del legislador a la jurisprudencia del Tribunal Constitucional, vid. M. AHUMADA RUIZ, V. FERRERES COMELLA, L. LÓPEZ GUERRA y C. VIVER PI-SUNYER, Com vinculen les sentències constitucionals el legislador, Institut d'Estudis Autonòmics, Barcelona, 2012. 
En segundo lugar, porque la doctrina del Tribunal Constitucional sobre el silencio negativo en vía de recurso y sus efectos sobre la ejecutividad de las sanciones, sentada por vez primera en su Sentencia 243/2006, no se estableció al hacer un juicio de inconstitucionalidad directo y abstracto sobre un precepto legal, sino que aquella sentencia resolvió un recurso de amparo que se otorgó por considerar que la argumentación de la sentencia impugnada ante el Tribunal Constitucional había sido "manifiestamente insuficiente», así como porque carecía de razonabilidad concluir, como había hecho aquella sentencia, que una sanción ha adquirido firmeza por el solo hecho de que hubiese transcurrido el plazo para dictar y notificar la resolución expresa del recurso, pues, a juicio del Tribunal, "el deber de la Administración de resolver el recurso y su potestad de hacerlo en sentido estimatorio, revocando o anulando totalmente la resolución impugnada en alzada, resultan incompatibles con la atribución de la nota de firmeza antes de la resolución expresa de aquél». Con base en ello, el Tribunal concluyó que la sentencia impugnada carecía de la razonabilidad exigida a las resoluciones judiciales, porque su razonamiento no permitía alcanzar su conclusión, dado que «no existe vinculación lógica directa entre su única premisa, la expiración de los plazos a que se refieren los artículos 115.2 LRJPAC y 46.1 LJCA, y la conclusión alcanzada».

Con independencia de las reflexiones críticas que cabría hacer sobre los pronunciamientos que se contienen en esta sentencia(19), lo que

(19) No este es lugar para analizar, a fondo, los pronunciamientos de esta sentencia, pero me parece que el Tribunal Constitucional fue demasiado lejos en esta ocasión, tratándose, como se trataba, de una cuestión de legalidad ordinaria, tal y como la calificó la propia sentencia, y teniendo en cuenta que, como también dijo en esta sentencia, «cuando lo que se debate es, como sucede en este caso, la interpretación y aplicación de preceptos legales que no afectan a derechos fundamentales susceptibles de amparo, sólo podrá considerarse que la resolución judicial impugnada vulnera el derecho a la tutela judicial efectiva cuando el razonamiento que la funda incurra en tal grado de arbitrariedad, irrazonabilidad o error que, por su evidencia y contenido, sean tan manifiestos y graves que para cualquier observador resulte patente que la resolución de hecho carece de toda motivación o razonamiento".

No entiendo cómo puede decirse que para cualquier observador resulta patente que carece de toda motivación o razonamiento una sentencia que concluye que la desestimación, por silencio administrativo, del recurso administrativo interpuesto contra una sanción, hace que la sanción adquiera firmeza y sea, por tanto, ejecutiva. No carece, a mi juicio, de toda motivación y razonamiento una resolución judicial que lo que hace es considerar que una sanción es firme -a efectos de ejecutividad - cuando, por aplicación del silencio administrativo, cabe entender desestimado el recurso administrativo interpuesto contra aquella, pues ¿acaso la firmeza administrativa no es - aparte de otros significados - la situación que se produce cuando el acto administrativo ya no puede ser objeto de recurso administrativo alguno y, además, está en disposición de ser recurrido en la vía contencioso-administrativa? Si a todo ello añadimos que era la propia Ley, aplicada en el caso de autos, la que decía que si un acto presunto no era recurrido en vía administrativa en plazo devenía firme a todos los efectos (artículo 115.1 LRJPAC), con mayor razón aún habría que considerar que al razonamiento judicial no le faltaba lógica y, por ello, resulta difícil entender que el Tribunal otorgara el amparo en este caso. Y, sobre todo, después de afirmar lo siguiente: "hemos venido exigiendo, pues, la coherencia lógica del razonamiento y excluyendo que puedan conside- 
quiero resaltar ahora es que el recurso de amparo se estimó porque el razonamiento de la sentencia impugnada - dando por bueno que una sanción es ejecutiva desde el momento en que el recurso de alzada interpuesto contra la misma haya sido desestimado por silencio- era insuficiente, irrazonable e ilógico, pero no porque el hecho de considerar ejecutiva una sanción desde el momento en que haya sido desestimado por silencio el recurso interpuesto contra la misma sea, en sí mimo, contrario al derecho fundamental a la tutela judicial efectiva. Es más, es la propia sentencia la que afirma que no puede descartarse que la cuestión debatida pudiera llegar a ser decidida de forma contraria a lo que alegaba el demandante (20) y que lo único que el Tribunal puede decir es que la sentencia impugnada "ha omitido premisas que justifiquen y expliquen su fallo», razón por la cual, si bien es cierto que estima el recurso de amparo, no lo es menos que decide «retrotraer las actuaciones al momento inmediatamente anterior al de dictar sentencia a fin de que dicho órgano jurisdiccional pronuncie otra, respetuosa con el derecho fundamental reconocido".

Y no ha sido esta la única ocasión en la que el Tribunal Constitucional ha reconocido que son posibles otras interpretaciones de la legalidad en relación con la cuestión de las sanciones y el silencio administrativo en vía de recurso. Así, en su Sentencia 37/2012, ya citada, y en las que reiteraron su doctrina (21), el Tribunal, refiriéndose a la cuestión del silencio administrativo y la prescripción de las sanciones, afirmó lo siguiente:

"...no corresponde al Tribunal Constitucional determinar cuál sea la interpretación preferible cuando son posibles - dentro de la Constitución - distintas interpretaciones judiciales de la legalidad ordinaria, y entre ellas pueda identificarse alguna que acaso hubiera respondido más plenamente a los valores incorporados a los derechos fundamentales $u$ otros preceptos constitucionales, pues una cosa es la garantía de los derechos fundamentales, tal y como le está encomendada a este Tribu-

\footnotetext{
rarse razonadas aquellas resoluciones judiciales respecto de las que, a primera vista y sin necesidad de mayor esfuerzo intelectual y argumental, se advierte que "parten de premisas inexistentes o patentemente erróneas o siguen un desarrollo argumental que incurre en quiebras lógicas de tal magnitud que las conclusiones alcanzadas no pueden considerarse basadas en ninguna de las razones aducidas"...". Decir que este era el caso es, cuando menos, exagerado, por las razones que he expuesto.

(20) Esencialmente, lo que alegaba el demandante es que no adquiere firmeza y, por tanto, no es ejecutiva una sanción hasta que no se resuelve de forma expresa el recurso interpuesto contra la misma.
}

(21) SSTC 91/2012, 93/2012 y 98/2012. 
nal, y otra, muy distinta, la de la máxima irradiación de los contenidos constitucionales en todos y cada uno de los supuestos de la interpretación de la legalidad [...].

No es ocioso señalar, en este sentido, que el propio Tribunal Supremo, de manera prudencial, advierte expresamente en su Sentencia en interés de ley de 22 de septiembre de 2008 (fundamento de Derecho quinto) que de la conjunción de la doctrina legal sentada en esta sentencia con la formulada en la anterior Sentencia en interés de ley de 15 de diciembre de 2004, pudieran derivarse "consecuencias indeseables, como sería la pervivencia indefinida de una resolución sancionadora que estuviese pendiente de recurso de alzada y de la que no pudiere predicarse la prescripción de la infracción ni de la sanción" [...]"

Pues bien, esta precaución del Tribunal Supremo, en lugar de debilitar la legitimidad constitucional de la doctrina legal en la referida Sentencia en interés de ley, la refuerza, toda vez que deja abierta la puerta a sucesivas reconsideraciones cuando el caso así lo precisare». La pertinencia de aplicar la doctrina del Tribunal Constitucional a la que acabamos de aludir en el párrafo anterior, referida a que no puede ser pretensión nuestra la de exigir la mejor solución o la más justa, de entre las posibles, cuando hay otras que, aun sin llegar a esos extremos, no obstante son constitucionalmente suficientes, resulta, a la vista de la aludida precaución del Tribunal Supremo, especialmente apropiada».

A la vista de todo lo expuesto, cabe concluir, pues, que la doctrina de la STC 243/2006, según la cual, mientras esté pendiente la resolución de un recurso administrativo contra una sanción, ésta no puede adquirir firmeza y no es ejecutiva, no impedía que el legislador estableciese que la desestimación por silencio del recurso determina el inicio del cómputo del plazo de prescripción de la sanción, que es lo mismo que decir que a partir de ese momento es ejecutable, pues, como ya he dicho, una cosa (el correr del plazo de prescripción de la sanción) no se entiende sin la otra (que la Administración pueda ejecutarla y tenga que ejecutarla dentro de un plazo de tiempo determinado). La legalidad ordinaria vigente en el momento en que se dictó esa sentencia y las otras que la confirmaron sencillamente ha sido sustituida por otra legalidad ordinaria que, no en vano, ha dejado de hablar de "firmeza" de las sanciones para definir cuándo son ejecutivas.

Tampoco considero que la doctrina constitucional sobre la configuración del silencio administrativo, en general, esto es, la que no se refiere 
específicamente a las sanciones, pueda ser un obstáculo frente a esta nueva regulación de la prescripción/ejecutividad de las sanciones administrativas, que determina, según la interpretación que sostengo, que, en los casos en los que el recurso administrativo haya sido desestimado por silencio, la sanción es ejecutable y, por consiguiente, empieza a correr el plazo de prescripción desde el día siguiente al que se produce el silencio administrativo negativo.

En primer lugar, conviene recordar cuál es, en esencia, la doctrina que el Tribunal Constitucional ha establecido sobre el silencio administrativo, y nada mejor para ello que hacerlo con el resumen que de la misma hace el propio Tribunal en su Sentencia 37/2012 (Fundamento jurídico 10):

"...por lo que se refiere a la doctrina constitucional sobre el silencio administrativo, este Tribunal tiene reiteradamente declarado que la figura del silencio es una mera "ficción legal, que responde a la finalidad de que el administrado pueda, previos los recursos pertinentes, llegar a la vía judicial superando los efectos de la inactividad de la Administración», de manera que en estos casos "no puede calificarse de razonable aquella interpretación que prima la inactividad de la Administración, colocándola en mejor situación que aquella en la cual se habría encontrado si hubiera cumplido su obligación de resolver" expresamente y hubiese efectuado la notificación procedente observando todos los requisitos legales (SSTC 6/1986, de 21 de enero, F.J. 3; 204/1987, F.J. 4; 188/2003, F. J. 6; 220/2003, F.J. 5; 14/2006, F.J. 2; y 40/2007, F.J. 2, entre otras muchas). Por ello, este Tribunal concluye que resultan contrarios al art. 24.1 CE los pronunciamientos judiciales de inadmisión de recursos contencioso-administrativos por extemporaneidad (por no haber impugnado judicialmente en su día la desestimación presunta del recurso administrativo) fundamentados en considerar la existencia de una resolución administrativa expresa dictada fuera de plazo sólo como un acto confirmatorio de lo ya resuelto de manera consentida y firme por silencio, en tanto que supone una interpretación irrazonable y contraria al principio pro actione deducir del comportamiento pasivo de quien recurre, derivado de la propia inactividad de la Administración, un consentimiento con el contenido de un acto administrativo que fue impugnado». 
Con independencia de que se comparta o no esta doctrina (22), lo que no debemos olvidar es que se dicta en relación a una cuestión muy concreta, cual es la de determinar si la decisión de inadmitir un recurso contra una resolución presunta, por el hecho de interponerlo fuera de plazo, resulta o no contraria al derecho a la tutela judicial efectiva, en su grado máximo de expresión que es el acceso a la jurisdicción. Es decir, que se trata de una doctrina sentada en un caso en el que el silencio administrativo entra -o puede entrar - en colisión con un derecho fundamental. Cosa que, para el Tribunal Constitucional, no ocurre cuando se trata de valorar los efectos del silencio en relación con la ejecutividad y la prescripción de las sanciones e infracciones. No hay más que recordar, a este respecto, que, en su Sentencia 243/2006 (Fundamento de Derecho 5), el Tribunal sostuvo que, en el caso allí enjuiciado (si la desestimación presunta de un recurso de alzada hacía firme y, por tanto, ejecutable a la sanción recurrida, o no), se trataba de una cuestión de uinterpretación y aplicación de preceptos legales que no afectan a derechos fundamentales susceptibles de amparo" (23). Siendo ello así, esta es una primera razón para considerar que no se puede trasladar, sin más, la doctrina constitucional sobre el silencio administrativo, establecida en relación con el acceso a los recursos, a cualquier cuestión que se plantee en relación con los efectos del silencio negativo.

Por otro lado, hay que tener en cuenta que el fundamento de esta doctrina constitucional radica - en palabras del propio Tribunal - en que «no puede calificarse de razonable aquella interpretación que prima la inactividad de la Administración, colocándola en mejor situación que aquella en la cual se habría encontrado si hubiera cumplido su obligación de resolver expresamente y hubiese efectuado la notificación procedente observando todos los requisitos legales». Si ello es así, lo que habría que concluir es que el criterio del Tribunal Supremo, avalado por el Tribunal Constitucional, según el cual mientras que la Administración no resuelva expresamente el recurso de alzada, no empieza a correr el plazo de prescripción de la sanción, sí que estaría "primando» la inacti-

(22) Me remito a lo dicho en «Silencio administrativo: delimitación jurisprudencial de su ámbito de aplicación (Comentario a la Sentencia del Tribunal Supremo de 28 de febrero de 2007)", en Cuadernos de Derecho Local, n. ${ }^{\circ} 16$, febrero de 2008, págs. 36-37.

(23) Vid. Tomás CANO CAMPOS, "La imprescriptibilidad de las sanciones recurridas o la amenaza permanente del ius puniendi de la Administración", en El Cronista del Estado social y democrático de Derecho, lustel, n. ${ }^{\circ} 30,2012$, pág. 79, para quien la interpretación que realiza el Tribunal Supremo sobre la prescripción de las sanciones que han sido recurridas en alzada y cuyo recurso no se ha resuelto de forma expresa (avalada por el Tribunal Constitucional en las sentencias tantas veces citadas 37/2012, 91/2012, 93/2012 y 98/2012) sí que estaría vulnerando el derecho fundamental a la legalidad sancionadora (artículo $25 \mathrm{CE}$ ). 
vidad administrativa y colocando a la Administración en mejor situación que si hubiera cumplido con su deber legal de resolver de forma expresa y en plazo el recurso, pues quedaría exclusivamente en sus manos decidir cuándo se extingue su potestad para ejecutar las sanciones o, incluso, si se extingue, pues bastaría con no resolver nunca, para que nunca prescribieran las sanciones.

Por eso, comparto plenamente la opinión de Tomás Cano cuando, refiriéndose a la interpretación del Tribunal Supremo sobre el artículo 132 de la LRJPAC, avalada por el Tribunal Constitucional, en su sentencia $37 / 2012$, dice que «la norma cuya constitucionalidad sostiene la mayoría del Tribunal Constitucional desvirtúa por completo la finalidad de la institución del silencio, pues transforma en una posición de ventaja lo que no es más que el incumplimiento de un deber legal de la Administración, provocando incertidumbre y unos efectos indeseables en los ciudadanos recurrentes que verán como el transcurso del tiempo (tanto cuanto quiera la Administración) en nada afecta a la consolidación de sus posiciones jurídicas y a la extinción de su responsabilidad por mucho que la ley haya previsto expresamente determinados plazos para ello" (24).

Así, pues, lejos de ser irrazonable una norma como la contenida en el artículo 30.3 de la LRJSP, que establece que las sanciones prescriben - a pesar de que el recurso administrativo no haya sido resuelto de forma expresa por la Administración - desde el momento en que se produzca su desestimación por silencio administrativo, en mi opinión es más que razonable $y$, desde luego, es la más respetuosa con la seguridad jurídica, que es el fundamento de una institución - la prescripciónque consiste en considerar extinguida una potestad administrativa cuando transcurre el tiempo máximo que ha establecido el legislador, sin que dicha potestad se ejercite.

El otro argumento que ha llevado al Tribunal Constitucional a considerar contrario al derecho a la tutela judicial efectiva el hecho de imponer plazos a los recursos contra el silencio negativo gira en torno al significado que el Tribunal ha atribuido a la expresión - contenida en la Ley 4/1999 (artículo 43.2) y reiterada hoy en la LPAC (artículo 24.2) - «la desestimación por silencio administrativo tiene los solos efectos de permitir a los interesados la interposición del recurso administrativo o contenciosoadministrativo que resulte procedente». Con base en esta interpretación, el Tribunal Constitucional, como es sabido, ha terminado declarando que el artículo 46.1 de la Ley 29/1998, Reguladora de la Jurisdicción contencioso-administrativa (LJCA), que establece un plazo de seis meses para re-

(24) Tomás CANO CAMPOS, "La imprescriptibilidad de las sanciones...», cit. pág. 76. 
currir los actos presuntos, ha dejado de ser aplicable en los supuestos de silencio administrativo negativo (STC 52/2014) (25).

En mi opinión, cabía hacer una interpretación distinta del artículo 43.2 de la LRJPAC que sería más respetuosa con la seguridad jurídica, por ser este un valor constitucional que aboga por la consolidación de las posiciones jurídicas $y$, se opone, por tanto, a que la posibilidad de recurrir un acto administrativo $y$, en general, cualquier acto jurídico, quede abierta sine die.

En efecto, para empezar, el precepto lo único que decía es que el silencio negativo tiene los solos efectos de permitir al interesado interponer los recursos procedentes, pero no añadía, a continuación, que el interesado pudiera hacerlo cuando quisiera. Es más, fue la propia ley la que no concebía que el silencio negativo pudiera recurrirse cuando el interesado quisiera, ya que, en su artículo 115.1, cuya redacción se mantuvo inalterada en la reforma de 1999, decía que, una vez transcurridos los plazos (en plural, pues la norma establecía dos plazos diferentes: un mes si el acto fuera expreso, y tres meses si no lo fuera), si no se recurría en alzada, "la resolución" - en ambos casos, pues, expresa y presunta-, "será firme a todos los efectos".

Siendo así, podría haberse interpretado que lo que quería hacer el legislador al establecer, en la Ley 4/1999, que el silencio negativo tiene los solos efectos de permitir el acceso al recurso - cosa que no cabría si no entendiésemos que hay un acto que recurrir - no era otra cosa que distinguirlo del silencio positivo, en el doble sentido de decir (i) que, una vez producido el silencio positivo, la Administración, si quisiera tomar una decisión expresa en sentido contrario, ya no podría, porque el silencio se considera a todos los efectos un acto, y tendría que acudir a la revisión de oficio y anularlo, si es que tuviera un vicio de nulidad; y (ii) que, por el contrario, el silencio negativo no produce ese efecto, sino que la Administración, que sigue obligada a dictar resolución expresa, no se encuentra vinculada al sentido desestimatorio que la ley atribuye al silencio administrativo en estos casos, sino que puede dictar una re-

(25) En el Fundamento de Derecho 5 de la STC 52/2014, el Tribunal declara que «con arreglo a la nueva ordenación del silencio administrativo introducida por la Ley 4/1999 ya no tienen encaje en el concepto legal de "acto presunto" los supuestos en los que el ordenamiento jurídico determina el efecto desestimatorio de la solicitud formulada, pues en tales supuestos el ordenamiento excluye expresamente la constitución ipso iure de acto administrativo de contenido denegatorion. Por tanto, concluye a continuación, "...habida cuenta de que [...] en los supuestos de silencio negativo ya no existe acto administrativo alguno finalizador del procedimiento (artículo 43.2 LPC), ni un acto administrativo denominado "presunto" basado en la ficción legal como se desprendía de la redacción originaria de la Ley 30/1992, [...], el inciso segundo del artículo 46.1 LJCA ha dejado de ser aplicable a dicho supuesto. En otras palabras, a la luz de la reforma de 1999 de la Ley 30/1992, la impugnación jurisdiccional de las desestimaciones por silencio no está sujeta al plazo de caducidad previsto en el artículo 46.1 LJCA». 
solución en el sentido - negativo o positivo- que considere procedente en Derecho.

En otras palabras, cabe pensar que lo único que quería decir el legislador es que el silencio negativo no produce ese efecto vinculante a su sentido que produce el silencio positivo y que, por el contrario, el efecto que produce es que el interesado, en lugar de quedarse esperando la resolución expresa de la Administración, está legitimado para impugnar el acto presunto en la vía - administrativa o judicial - que en cada caso resulte procedente. La palabra "solos", referida a los efectos del silencio negativo, si no se saca del contexto de lo que se está regulando en ese precepto, no debería significar otra cosa distinta a la que aquí acabo de exponer, y ello porque el propio legislador, en otro precepto, al regular los plazos de los recursos, daba por hecho que el silencio también debía ser recurrido en plazo, eso sí, en un plazo más amplio que el establecido para los recursos contra actos expresos. Si a ello añadimos que la LJCA - seis meses posterior a la Ley 4/1999, pero elaborada y tramitada en gran parte en paralelo a esta última - estableció un plazo de seis meses para recurrir el silencio (frente al de dos meses, para el recurso contra actos expresos), me parece más que razonable concluir que, en ambos casos, el legislador había considerado compatible su concepción del silencio administrativo negativo con el sometimiento a plazo de su impugnación. Y, en efecto, en mi opinión, ambas cosas no solo pueden, sino que deberían ser compatibles, ya que resulta más respetuoso con la seguridad jurídica establecer plazos amplios para recurrir el silencio, que dejar la posibilidad de recurrir a la disposición total de una parte, ya que por el hecho de que se trate de actos desestimatorios para el interesado, no puede excluirse que puedan afectar a los derechos o intereses legítimos de terceros.

A este respecto, conviene recordar que el Tribunal de Justicia de la Unión Europea ha considerado conforme a Derecho la decisión de inadmitir un recurso interpuesto fuera de plazo contra una desestimación presunta, y ello por entender que, conforme a una jurisprudencia reiterada de dicho tribunal, "los plazos para recurrir no tienen carácter dispositivo ni para el Juez ni para las partes» (26).

\footnotetext{
(26) Auto del Tribunal General, Sala Cuarta, de 13 de noviembre de 2012, en el asunto T-278/1, en cuyo apartado 46 declara : «En efecto, tal como recuerda el Tribunal en el anterior apartado 31, conforme a una jurisprudencia reiterada, los plazos para recurrir no tienen carácter dispositivo ni para el Juez ni para las partes. Pues bien, considerando, según se desprende de los escritos de 4 de mayo y de 29 de junio de 2012, a la luz del intercambio de correspondencia entre las demandantes y la Comisión, que la decisión denegatoria presunta, en el sentido del artículo 8, apartado 3, del Reglamento n. ${ }^{\circ}$ 1049/2001, se produjo el 22 de abril de 2011, resulta manifiesto que las demandantes pretendieron dotar al plazo para interponer el recurso de anulación de carácter dispositivo, retrasando la fecha de la formación de dicha decisión y, en consecuencia, la fecha a partir de la que había comenzado a correr el plazo de que disponían para interponer dicho recurso y también la fecha en la que había finalizado».
} 
Ahora bien, dicho todo ello, la cuestión es que la LPAC no solo mantiene la expresión "a los solos efectos", cuando distingue el silencio negativo del positivo (artículo 24.2 LPAC), sino que, además, ahora ha establecido que el recurso, ya sea de alzada o de reposición, si es contra un acto que no es expreso, se podrá interponer "en cualquier momento", a partir del día siguiente a aquel en el que se produzca el acto presunto (artículos 122.1 y 124.1 de la LPAC). La ley debería haber aclarado, por cierto, que la inexistencia de plazo para recurrir lo es en relación con un acto presunto de sentido negativo, pues resultaría contrario a la concepción del silencio positivo como un verdadero acto administrativo, a todos los efectos, considerar que éste se puede recurrir (por un tercero legitimado y en contra de los intereses de quien ha visto estimada su pretensión por silencio positivo), en cualquier momento. Es más, si se interpretara la expresión "acto presunto» en el sentido en que lo ha hecho el Tribunal Constitucional en su Sentencia $52 / 2014$, esto es, considerando que solo puede haber un acto presunto y que ese único acto presunto posible es el producido por silencio positivo, mientras que el acto presunto negativo no sería tal acto (27), resultaría que los artículos 122.1 y 124.1 de la LPAC habrían venido a consagrar la regla de que el silencio positivo (el único acto presunto existente, según el Tribunal Constitucional) puede recurrirse sin sometimiento a plazo alguno.

Pero volviendo a la cuestión que nos ocupa, y para terminar con los argumentos que, en mi opinión, llevarían a concluir que la doctrina constitucional sobre el silencio administrativo no se opone a una regulación como la establecida ahora en el artículo 30.3 de la LRJSP, considero que no hay contradicción alguna en que la ley diga, por un lado, que el silencio negativo tiene "los solos" efectos de permitir al interesado recurrir el acto presunto negativo, en lugar de esperar al acto expreso - que puede ser negativo o positivo - que, por otro lado, establezca que la desestimación de los recursos administrativos por silencio sí produce un efecto, cual es el de que, a partir del día siguiente de producirse el silencio en un recurso administrativo interpuesto contra una sanción administrativa, el plazo de prescripción de la sanción comienza a contarse, siendo ello así porque, también, a partir de ese momento, hay que entender que la sanción es ejecutable.

(27) Es precisamente con base en esta interpretación, que me atrevería a calificar de nominalista, que el Tribunal Constitucional ha concluido, como ha quedado expuesto en la nota 26, que el inciso del artículo 46.1 de la LJCA, que establece que el plazo para recurrir "los actos presuntos" es de seis meses, ha dejado de ser aplicable, porque los actos producidos por silencio negativo no son, realmente, actos administrativos. Es decir que, para el Tribunal Constitucional "en los supuestos de silencio negativo [...] ya no existe [...] un acto administrativo denominado"presunto"". 
Aun aceptando que la expresión "los solos efectos" del artículo 24.2 de la LPAC signifique que queda excluido cualquier otro efecto para el silencio negativo que no sea el de permitir al interesado recurrirlo, no habría ninguna contradicción ni incoherencia entre ese precepto y el artículo 30.3 de la LRJSP, porque lo que habría que entender, en tal caso, es que la ley habría establecido una regla, pero también una excepción a esa regla, con la que, por lo demás, vendría a ponerse fin a ese efecto indeseado y contrario a la seguridad jurídica que produce el considerar, como han hecho el Tribunal Supremo y elTribunal Constitucional, si bien con los votos particulares en contra de varios magistrados, que la prescripción de una sanción puede llegar a no producirse nunca, si así lo quiere la Administración (28).

Por todo ello, en mi opinión, la norma establecida en el artículo 30.3 de la LRJSP es una norma razonable y respetuosa con la Constitución, en cuanto que encuentra fundamento en el principio de seguridad jurídica (artículo 9.3 CE). Además, creo que merece una valoración positiva, porque viene a poner algún límite a los excesos en los que, en materia de silencio administrativo, ha incurrido, en mi opinión, la jurisprudencia.

El silencio administrativo es una patología que no se cura con más patologías, como lo es, en mi opinión, el establecer que un acto pueda ser impugnado sine die; que una sanción pueda no prescribir nunca; o que una sanción pueda no llegar a hacerse cumplir nunca, si así lo quiere la Administración, bastándole para ello con no resolver el recurso administrativo interpuesto contra la misma. La seguridad jurídica exige que haya plazos, aunque sea amplios, para recurrir, como también los exige para que la Administración pueda ejercer su potestad de ejecutar la sanción, y para que el sujeto sancionado sepa que, llegado un momento, su sanción ya no podrá ser ejecutada. Dejando la duración del plazo de prescripción en manos de la Administración sine die, se perjudica al sujeto infractor, ya que no tendrá nunca la seguridad de que la sanción vaya a prescribir, pero también se puede perjudicar al interés general y a posibles intereses de terceros a los que pueda beneficiar la ejecución de la sanción.

Todo lo cual pone de manifiesto que solo desde una perspectiva muy parcial puede concebirse que el silencio sea, exclusivamente, un problema entre una Administración que incumple su deber legal de resolver en plazo y un ciudadano que tiene derecho a la resolución expresa, y en

(28) Los Magistrados E. Gay, P. PérezTremps, A. Asua y L. Ortega, en sus votos particulares a la STC $37 / 2012$, consideran contraria a la seguridad jurídica la doctrina legal del Tribunal Supremo sobre la prescripción de las sanciones en los casos en los que no hay resolución expresa del recurso administrativo. 
plazo, de sus solicitudes y recursos, pues hay que considerar el interés general en juego y también los intereses de terceros. Por eso, en términos de seguridad jurídica, no me parece que la solución a este eterno e incorregible incumplimiento de la legalidad por parte de la Administración que es el silencio administrativo sea "compensar" al sujeto sancionado con la no ejecutividad de la sanción y "castigarlo", por cierto, y al mismo tiempo, con la no prescripción de su sanción. La solución pasa por exigir responsabilidades a quienes no dictan resolución en plazo, pues, salvo casos excepcionales, no parece que sea tan difícil estimar o desestimar, en plazo, un recurso teniendo en cuenta que a las resoluciones administrativas solo se les exige motivar con "con sucinta" referencia a hechos y fundamentos de Derecho.

\section{La ejecutividad de la sanción una vez que ya es ejecutable y antes de que transcurra el plazo para recurrirla ante la Jurisdicción contencioso-administrativa}

La otra gran novedad de la LPAC, en materia de ejecutividad de las sanciones, es la que se establece en relación con el estado en que queda una sanción una vez que ya es ejecutable, pero todavía está abierto el plazo para interponer el recurso contencioso-administrativo contra la misma.

El artículo 90.3 de esta ley establece lo siguiente:

"Cuando la resolución sea ejecutiva, se podrá suspender cautelarmente, si el interesado manifiesta a la Administración su intención de interponer recurso contencioso-administrativo contra la resolución firme en vía administrativa. Dicha suspensión cautelar finalizará cuando:

a) Haya transcurrido el plazo legalmente previsto sin que el interesado haya interpuesto recurso contencioso administrativo.

b) Habiendo el interesado interpuesto recurso contenciosoadministrativo:

1. ${ }^{\circ}$ No se haya solicitado en el mismo trámite la suspensión cautelar de la resolución impugnada.

2. ${ }^{\circ}$ El órgano judicial se pronuncie sobre la suspensión cautelar solicitada, en los términos previstos en ella».

El precepto, con algunas imprecisiones terminológicas, a las que luego haré referencia, viene a establecer un régimen especial, y más favorable, de tutela cautelar frente a las sanciones administrativas, consis- 
tente en que, una vez que la sanción es ejecutiva, situación que se da, como sabemos, cuando no quepa contra ella recurso administrativo ordinario alguno, se producirá la suspensión por el solo hecho de que el interesado manifieste a la Administración su intención de interponer recurso contencioso-administrativo. A pesar de la ambigüedad de la expresión utilizada por el legislador - «se podrá suspender cautelarmente»-, para mí es claro que lo que ha querido decir la ley es que, si el interesado dirige un escrito a la Administración comunicándole su intención de interponer un recurso contencioso-administrativo contra la desestimación de su recurso administrativo previo o, directamente, contra la sanción, si contra ella procede recurso potestativo de reposición, entonces se producirá la suspensión automática de la ejecutividad de la sanción. Entender que el legislador ha querido decir que, en estos casos, se podrá, o no, suspender la ejecutividad de la sanción carece de sentido, en mi opinión, y ello porque la actuación del interesado consiste en poner en conocimiento de la Administración su intención de recurrir, y no en presentarle una solicitud de suspensión que la Administración tenga que resolver y, por tanto, pueda resolver en un sentido (estimatorio) o en otro (desestimatorio). No hay tal posibilidad de pronunciamiento por parte de la Administración, y lo que se produce, por consiguiente, es un efecto automático de suspensión como consecuencia del acto de comunicación del interesado.

La regla ahora $-y$ ahí radica su novedad- es que la comunicación por parte del interesado a la Administración de su intención de recurrir la sanción en el contencioso-administrativo suspende de forma automática su ejecutividad y, por eso, el precepto completa esta regla - de suspensión automática y temporal- con otras sobre la duración de la suspensión, estableciendo que la ejecutividad estará suspendida hasta que se produzca una de estas tres circunstancias: (i) que transcurra el plazo de dos meses para interponer el recurso contencioso-administrativo y el interesado no lo interponga; (ii) que el interesado lo interponga dentro de plazo, pero no solicite la suspensión de la sanción en el escrito de interposición; y (iii) que, habiéndose interpuesto el recurso contencioso en plazo, y habiéndose solicitado la suspensión - en el momento de la interposición y no en cualquier otro momento(29) -, el órgano judicial no otorgue la suspensión solicitada. En este último supuesto, lo que determina el cese de la suspensión no es, como impropiamente dice la ley, "que el órgano judicial se pronuncie sobre la suspensión cautelar solicitada", pues si se pronunciara otorgándola, es evidente que la suspensión obtenida de forma automática y provisional no se extinguiría, sino que se

(29) El artículo 90.3.b).1. ${ }^{\circ}$ dice "en el mismo trámite», refiriéndose a la interposición del recurso. 
mantendría. Lo que razonablemente hay que entender que pone fin a la suspensión no es cualquier pronunciamiento sobre la solicitud de suspensión, sino solamente un pronunciamiento judicial desestimatorio de la misma (30).

Aparte de lo que acabo de señalar, el precepto deja un "fleco suelto", cual es el de que no prevé mecanismo alguno para que la Administración pueda tener conocimiento, de forma fehaciente y a su debido tiempo, de que se han producido las circunstancias que determinan el cese de la suspensión. Por tanto, y salvo en el supuesto de la desestimación de la suspensión por el órgano judicial, en el que la Administración tendrá conocimiento de la denegación de la suspensión desde el momento en que se le notifique el auto de medidas cautelares, en los otros dos supuestos - no presentación del recurso contencioso-administrativo en plazo y presentación sin solicitar la suspensión en el escrito de interposición- tendrá que ser la propia Administración la que realice las gestiones oportunas para poder saber a partir de qué momento es ejecutable la sanción. En mi opinión, este problema se podría haber evitado si el legislador hubiese establecido que el interesado, de la misma manera que tiene que comunicar a la Administración su intención de interponer recurso contencioso-administrativo si quiere que se produzca la suspensión automática de la ejecutividad de su sanción, debe también comunicarle, llegado el momento, que ha interpuesto el recurso judicial y que ha solicitado la suspensión. No habiéndolo previsto así el legislador, entiendo que el interesado no puede resultar obligado a ello por la propia Administración, pues le faltaría la habilitación legal expresa para imponerle un deber de esta naturaleza, especialmente necesaria tratándose de un acto administrativo de naturaleza sancionadora.

A propósito de este novedoso precepto, y poniéndolo en relación con la interpretación que aquí he mantenido sobre el artículo 30.3 de la LRJSP y sus consecuencias sobre la ejecutividad de las sanciones en los casos de desestimación presunta del recurso administrativo, resultaría que, ahora, en la hipótesis de que mi interpretación fuese correcta, las sanciones recurridas en vía administrativa serían ejecutivas a partir del día siguiente en que se produjese el silencio, pero, si se quiere, ese mismo día, la ejecutividad quedaría suspendida con tal de que el sancionado comunicase a la Administración su intención de recurrirla en el contencioso. A su vez, dicha suspensión, como ha quedado expuesto, cesaría si, transcurrido el plazo del recurso contencioso-administrativo, el interesado no lo interpusiera. Ahora bien, ¿cuál sería el plazo para interponer el recurso contencioso en los casos en los que el recurso administrativo no se hu-

(30) Así lo entienden también Luis MARTíN REBOLLO, "La potestad sancionadora...», cit. pág. 365 y Tomás CANO CAMPOS, "El autismo del legislador...», cit. pág. 51. 
biera resuelto de forma expresa? La respuesta a esta pregunta ya la conocemos: ninguno, porque el Tribunal Constitucional ha dicho que el inciso del 46.1 de la LJCA, que es el que establece el plazo de seis meses para el recurso contra los actos producidos por silencio negativo, hay que tenerlo por no puesto $y$, por consiguiente, como ya no es de aplicación en nuestro ordenamiento jurídico, resulta que no hay plazo para recurrir estos actos ante la Jurisdicción contencioso-administrativa.

Siendo ello así, se daría la paradoja de que, a pesar de que el legislador ha otorgado unos efectos al silencio producido en vía de recurso (el inicio del cómputo de la prescripción de la sanción) que, en buena lógica, deberían conllevar, como presupuesto, que el silencio en vía de recurso hace a la sanción ejecutable, resulta que la aplicación de una doctrina constitucional que ni siquiera ha dicho que el plazo de seis meses para recurrir el silencio ante el contencioso vulnere la Constitución, sino que, debido a la sucesión de dos normas en el tiempo, ese plazo no es aplicable, produciría como resultado que, con la nueva regulación, una sanción recurrida en vía administrativa, cuyo recurso no ha sido resuelto de forma expresa, empezaría a prescribir con su desestimación presunta, pero no podría ejecutarse si el sancionado comunica a la Administración su intención de recurrir en la vía contenciosa, con lo cual, y en ello radica la paradoja, se estaría extinguiendo, por el transcurso del tiempo sin ejercerla, una potestad administrativa - la de ejecutar las sanciones - a pesar de no haber tenido la Administración la posibilidad de ejecutarla.

La última cuestión que cabría plantear en relación con el artículo 90.3 de la LPAC es la de si la nueva regla sobre la ejecutividad, establecida solamente para las sanciones, no debería haberse previsto, con carácter general, para todos los actos administrativos, como, en mi opinión, exige el derecho fundamental a la tutela judicial efectiva, en su vertiente de tutela cautelar, tal y como ha sido interpretado por el Tribunal Constitucional y por el Tribunal Supremo. Estableciendo la regla en cuestión solamente para las sanciones administrativas, el legislador ha perdido la ocasión de poner fin al estado de confusión en el que se encuentra la cuestión de la suspensión de los actos administrativos en el período que media entre el momento en el que se desestima el recurso administrativo y el momento en el que órgano judicial se pronuncia sobre la suspensión solicitada en vía contencioso-administrativa.

Aunque esta es una cuestión que nos aleja del tema que nos viene ocupando, ya que se refiere a los actos administrativos, en general, y no específicamente a las sanciones, no es posible dejar de abordarla ante la novedad que supone un precepto como el artículo 90.3 de la LPAC. Para ello, es necesario recordar, brevemente, cuál es el régimen jurídico de la suspensión de los actos administrativos, refiriéndonos, en primer lugar, a su regulación y, en segundo lugar, a la jurisprudencia que la ha interpretado. 


\section{La regulación de la suspensión de los actos administrativos en la LPAC y en la LJCA}

Como es bien sabido, salvo en algunos ámbitos específicos, en los que está previsto expresamente que la interposición del recurso administrativo suspende (31), la regla general en el procedimiento administrativo común es que la interposición de un recurso administrativo no suspende y que, por consiguiente, el acto es ejecutivo salvo que el órgano competente para resolver el recurso acuerde su suspensión, cuando se den las circunstancias legalmente previstas para ello, a saber: el periculum in mora o el fumus boni iuris, entendiendo por tal que el recurso esté fundando en una causa de nulidad de pleno derecho (artículo 117.2 de la LPAC) (32).

Si esta es la regla en relación con la suspensión de la ejecutividad de los actos administrativos en vía de recurso administrativo, las cosas no son muy distintas en el contencioso-administrativo, pues, si bien es cierto que el artículo 129 de la LJCA no dice, como hace el artículo 117 de la LPAC, que la interposición del recurso no suspende la ejecutividad del acto administrativo impugnado, en la práctica es como si lo dijera, ya que lo que este precepto establece es que el órgano judicial, "podrá» (33) otorgar la suspensión solicitada si, previa valoración circunstanciada de todos los intereses en presencia, la ejecución del acto pudiera hacer perder su finalidad legítima al recurso. Es decir, que en el recurso contencioso-administrativo hay que solicitar la suspensión de la ejecutividad y, solo si el órgano judicial la otorga, el acto administrativo se verá privado «cautelarmente», esto es, mientras dura el proceso, del atributo de la ejecutividad.

(31) Además del ámbito sancionador, está previsto así, por ejemplo, para el recurso contra el acuerdo de necesidad de ocupación en la Ley de Expropiación forzosa, de 16 de diciembre de 1954 (artículo 22.3); en el recurso especial en materia contractual interpuesto contra el acto de adjudicación del contrato (artículo 53 de la Ley 9/2017, de Contratos del Sector público) y, como regla general, en el ámbito tributario (artículos 224 y 233 de la Ley 58/2003, General Tributaria).

(32) Sobre el artículo 111 de la Ley 30/1992, que establecía esta regla, y la crítica al mismo, me remito a C. CHINCHILLA MARÍN, "La tutela cautelar", en Comentarios a la Ley de la Jurisdicción contencioso-administrativa, dirigidos por J. LEGUINA VILLA y M. SÁNCHEZ MORÓN, Lex Nova, 2001, y, de la misma autora, "Criterios de adopción de las medidas cautelares en la nueva Ley Reguladora de la Jurisdicción Contencioso-administrativa», en Cuadernos de Derecho Judicial, CGPJ, 1999.

(33) De nuevo la forma verbal utilizada - «podrá» - no es la más adecuada, ya que, en realidad, cuando se da esa circunstancia, por exigencias del artículo 24 CE (derecho a la tutela cautelar), debería otorgarse la medida cautelar solicitada. Sobre la cuestión de la tutela cautelar y su naturaleza de derecho fundamental, por ser un instrumento necesario para garantizar la efectividad de la tutela judicial que la Constitución reclama, me remito a todo lo dicho en C. CHINCHILLA MARíN, La tutela cautelar en la nueva justicia administrativa, Civitas, 1991; "El derecho a la tutela cautelar como garantía de la efectividad de las resoluciones judiciales, RAP 131, 1993; y también en C. CHINCHILLA MARÍN "Criterios de adopción...», cit. y «La tutela cautelar...» cit. 
Dicho ello, podría pensarse que, hasta que esa circunstancia no se produzca, esto es, hasta que la suspensión no haya sido otorgada, bien en la vía administrativa, bien en la vía judicial, la Administración puede ejecutar sus actos. Y, sin embargo, ello no es así exactamente, debido a que existe una jurisprudencia, tanto del Tribunal Constitucional como del Tribunal Supremo, que ha venido a establecer, de forma reiterada, que, una vez que se ha solicitado la suspensión de un acto administrativo, mientras no se resuelva sobre su procedencia, la Administración no puede ejecutar el acto recurrido. El legislador ha hecho caso omiso de esa jurisprudencia $y$, en lugar de establecer las reglas necesarias para que la regulación de la ejecutividad de los actos administrativos recurridos esté en consonancia con el criterio que los Tribunales han extraído del artículo 24 de la Constitución, ha seguido regulando esta cuestión como si esa jurisprudencia no existiera.

Recordemos, de forma resumida, lo que los Tribunales han establecido al respecto.

\section{La jurisprudencia del Tribunal Constitucional y del Tribunal Supremo en materia de ejecutividad y suspensión de los actos administrativos: la tutela cautelar como derecho fundamental}

En la Sentencia del Tribunal Constitucional en la que se estableció la doctrina que acabo de resumir - la 78/1996 - el Tribunal otorgó el amparo a un ciudadano por considerar que se había lesionado su derecho a la tutela judicial efectiva debido a que la Administración había procedido a ejecutar la sanción que le había impuesto, a pesar de que la misma estaba recurrida (en reposición) y no se había resuelto todavía ni el recurso ni la solicitud de suspensión formulada en dicho recurso.

En esta sentencia, el Tribunal Constitucional, aplicando la doctrina que hasta ese momento había establecido sobre la tutela cautelar en el proceso contencioso-administrativo, declaró lo siguiente:

«El derecho a la tutela judicial se extiende a la pretensión de suspensión de la ejecución de los actos administrativos que, si formulada en el procedimiento debe permitir la impugnación de su denegación, y, si se ejercitó en el proceso, debe dar lugar en el mismo a la correspondiente revisión específica. El derecho a la tutela judicial efectiva se satisface, pues, facilitando que la ejecutividad pueda ser sometida a la decisión de un Tribunal y que éste, con la información y contradicción que resulte menester, resuelva sobre la suspensión (STC 66/1984). Si, pues, hemos declarado que la tutela se sa- 
tisface así, es lógico entender que mientras se toma aquella decisión no pueda impedirse ejecutando el acto, con lo cual la Administración se habría convertido en Juez. Los obstáculos insalvables a esta fiscalización lesionan, por tanto, el derecho a la tutela judicial efectiva».

Podría pensarse que con esta última afirmación («los obstáculos insalvables" a la fiscalización judicial de la ejecutividad de los actos administrativos lesionan el derecho a la tutela judicial efectiva), el Tribunal estaría queriendo decir que, para que haya lesión del derecho fundamental a la tutela cautelar, tiene que darse una suerte de irreversibilidad en lo ya ejecutado por la Administración.

No creo, sin embargo, que ello sea así, ya que el Tribunal no dice que la lesión, por la que otorgó el amparo, se produjera por haber hecho perder a la tutela judicial su efectividad, como consecuencia de haberse causado unos concretos daños de imposible reparación, sino por haberse impedido, en abstracto, y sin más, la revisión jurisdiccional de la ejecutividad del acto administrativo, ya que, en aquel supuesto, se había ejecutado un acto cuando dicho acto - una sanción - estaba pendiente de recurso administrativo y de una solicitud de suspensión. En mi opinión, ello queda suficientemente claro en el siguiente pronunciamiento de la sentencia:

"La cuestión radica, pues, precisamente en que se ordenase ejecutar la sanción sin esperar a su firmeza y aun sin haber resuelto ni el recurso de reposición ni la solicitud de suspensión...Y aunque también es cierto que, en el proceso de impugnación del acto sancionador (...) podría obtenerse no sólo una resolución de fondo sobre su legalidad sino, eventualmente, un Acuerdo de suspensión, éste sería evidentemente tardío y entre tanto se habría consumado la indefensión del sancionado en cuanto a su solicitud de suspensión del acto que no hubiera podido ser ya revisada por el Tribunal competente. Ello lesiona, de modo evidente, el artículo 24.1 CE al impedir el acceso de dicha petición al Juez y, en consecuencia, hace que proceda la estimación del amparo» (34).

De lo dicho se desprende, pues, que lo que lesiona el artículo 24.1 de la CE, según el Tribunal Constitucional, es el hecho de que la Administración ordene la ejecución de un acto cuando está pendiente de re-

(34) La cursiva no está en el texto original. 
solución el recurso administrativo y la solicitud de suspensión, pues es obvio que, en relación con lo que haya sido ejecutado por la Administración, el Juez ya no podrá ser quien decida si procede o no esa ejecución. Si, como ha dicho el Tribunal Constitucional, el artículo 24 de la CE exige que la ejecutividad de los actos administrativos pueda ser sometida a una decisión judicial, para evitar que el tiempo que dura el proceso acabe privándolo de su utilidad, es evidente que la Administración no debería poder ejecutar su acto antes de que el órgano judicial adopte una decisión sobre la ejecutividad del mismo, porque, si así lo hiciera, sería ella y no el juez quien decidiría sobre dicha ejecutividad, con lo cual no sólo se estaría vulnerando el artículo 24.1 de la Constitución, sino también el 117.3, que establece que la potestad jurisdiccional, juzgando y haciendo ejecutar lo juzgado, corresponde exclusivamente a los Jueces y Tribunales (35).

Esta ha sido, por lo demás, la conclusión que el Tribunal Supremo ha extraído de la doctrina del Tribunal Constitucional, como se pone de manifiesto en el siguiente pronunciamiento del Auto de 12 de julio de 2000:

«El Tribunal Constitucional en su sentencia de 17 de junio de 1982, tuvo ya ocasión de pronunciarse sobre la eventual oposición que podía darse entre el principio de ejecutividad de los actos administrativos y el citado derecho a la tutela judicial efectiva, y desde su sentencia 66/1984, de 6 de junio, viene armonizando, en términos de principios, ambas exigencias, afirmando que se concilian cuando se hace posible que la ejecutividad del acto administrativo pueda ser sometida a un Tribunal para que adopte la medida pertinente sobre la suspensión, especificando, además, que mientras se toma la decisión judicial sobre la suspensión cautelar, ésta no debe verse impedida por la ejecución del acto" (36).

Con más claridad, aun, citando la STC 78/1996, el Tribunal Supremo ha mantenido este criterio, en su Sentencia de 24 de noviembre de 2004, afirmando que

«Esta Sala [...] ha recordado que la STC 78/1996, de 20 de mayo, declaró: "el derecho a la tutela judicial se extiende a la

(35) Así lo manifesté y argumenté en C. CHINCHILLA MARÍN, "La tutela cautelar en la nueva justicia...", cit. págs. 162-163.

(36) Auto del Tribunal Supremos de 12 de julio de 2000, recurso n. ${ }^{\circ} 490 / 2000$. La cursiva no está en el texto original. 
pretensión de suspensión de la ejecución de los actos administrativos que, si formulada en el procedimiento debe permitir la impugnación de su denegación, y, si se ejercitó en el proceso, debe dar lugar en el mismo a la correspondiente revisión específica"».

Con base en el razonamiento anterior, el Tribunal Supremo concluye que el derecho a la tutela judicial se satisface cuando, antes de la ejecución, se permite someter a la decisión de los órganos judiciales la ejecutividad de los actos administrativos para que puedan resolver sobre la misma y que, por tanto, "se vulnera ese derecho fundamental, no cuando se dictan actos que gozan de ejecutividad, sino cuando, en relación con los mismos, se inician actos materiales de ejecución, sin ofrecer al interesado la posibilidad de instar judicialmente la suspensión de esa ejecutividad" (37).

Asimismo, refiriéndose también a la doctrina establecida en la STC 78/1996, el Tribunal Supremo ha declarado, en su Sentencia de 9 de febrero de 2010, que:

"Lo que conlleva esta doctrina es que, sometida a control jurisdiccional una resolución administrativa, y solicitada la suspensión de ejecución de la misma, no cabe que la Administración ejecute hasta que el órgano jurisdiccional se pronuncie» (38).

Recientemente, en su Auto de 2 de marzo de 2016, el Tribunal Supremo ha mantenido con toda claridad este criterio, en un pronunciamiento, que, aunque extenso, conviene reproducir:

"Ciertamente, si el derecho a la tutela judicial efectiva se satisface, según la doctrina reiterada del Tribunal Constitucional "facilitando que la ejecutividad pueda ser sometida a la decisión de un Tribunal y que éste, con la información y contradicción que resulta menester, resuelva sobre la suspensión" (STC 66/1984, de 6 de julio), significa en primer lugar, que mientras que los jueces y tribunales resuelven sobre una demanda de tutela cautelar en un recurso contencioso-administrativo no puede la Administración ejecutar el acto cuya legalidad se cuestiona, pues tal proceder estaría impidiendo al

(37) SSTS de 24 de noviembre de 2004, recurso n. ${ }^{\circ} 3071 / 2001$; la cursiva no está en el texto original. En el mismo sentido, la STS de 17 de julio de 2001, recurso n. ${ }^{\circ}$ 503/1997.

(38) STS de 9 de febrero de 2010, recurso n. ${ }^{\circ} 2431 / 2007$. 
órgano judicial pronunciarse de manera efectiva sobre la tutela cautelar.

La Administración, por tanto, no puede ejecutar un acto administrativo que ha sido recurrido por el interesado y se ha solicitado la adopción de medidas cautelares.

No supone, en consecuencia, que la prerrogativa de autotutela no siga siendo una característica del acto administrativo, que lo es. Sucede que únicamente cuando se cuestiona la legalidad del acto administrativo y la procedencia de su ejecución inmediata - mediante la correspondiente petición de tutela cautelar - debe permitirse que el órgano judicial conozca y se pronuncie sobre la procedencia o no de la ejecución del acto administrativo impugnado.

Dicho de otra forma, durante el tiempo que media entre la formulación de la solicitud de la medida cautelar y su adopción ¿puede la Administración ejecutar el acto administrativo recurrido?

Esta cuestión ha sido resuelta, así STC 78/1996, de 20 de mayo, por la doctrina constitucional al estimar un recurso de amparo interpuesto contra la ejecución por la Administración de una sanción, a pesar de que la misma había sido recurrida en vía contencioso-administrativa con solicitud cautelar.

Es lógico entender que mientras se toma aquella decisión sobre la suspensión, no pueda impedirse ejecutando el acto, con lo cual la Administración se habría convertido en Juez» (39).

Frente a estos pronunciamientos, en los que, como se ha visto, el Tribunal Supremo aplica - extrayéndola de la jurisprudencia constitucio-

(39) Auto del Tribunal Supremo, de 2 de marzo de 2016, recurso $n .{ }^{\circ} 4100 / 2015$. Creo que el Tribunal Supremo, inadvertidamente, comete un error, pues, en el caso de la STC 78/1996, la orden de ejecución de la sanción se dio cuando estaba pendiente de resolución el recurso administrativo de reposición y la solicitud de suspensión. Lo que se recurrió en el contencioso-administrativo no fue la sanción, sino la orden de ejecución de la misma. La sanción se recurrió en reposición (Antecedente 2, apartados c y d). En mi opinión, eso no cambia la doctrina que el Auto del Tribunal Supremo reproduce y la conclusión que extrae de la misma, pues, al fin y al cabo, en ese caso el Tribunal Constitucional entendió que si se ejecutaba el acto en ese momento, se estaba imposibilitando que un órgano judicial pudiera, en el futuro, fiscalizar su ejecutividad y pronunciarse sobre la misma. El propio Tribunal Constitucional diría, años después, en su Sentencia 243/2006, que si en ese caso se concedió el amparo «no fue porque considerásemos improcedente la ejecución sin la previa resolución del recurso administrativo pendiente, sino porque en las circunstancias de aquel caso la ejecución inmediata impidió al recurrente obtener de los Tribunales un pronunciamiento sobre la suspensión de la ejecución que consideramos lesivo del artículo 24.1 CE (F.5)». 
nal- la regla de que mientras que el órgano judicial no tome la decisión sobre la suspensión de un acto administrativo, la Administración no puede ejecutarlo, existen otros en los que el Tribunal Supremo ha introducido algún matiz al respecto.

Así, por ejemplo, en su STS de 9 de febrero de 2010, tras afirmar, con rotundidad, que lo que conlleva la doctrina de la STC 78/1996 es que, solicitada la suspensión de la ejecución, no cabe que la Administración ejecute el acto impidiendo que los órganos judiciales se pronuncien sobre ello, añade lo siguiente:

"Ahora bien, lo que no conlleva esta doctrina es que la Administración, con una resolución firme en vía administrativa, deba esperar el plazo de dos meses que tiene el interesado para recurrir un acto administrativo en vía jurisdiccional para poder ejecutar, pues ello sería tanto como decir que, en todo caso, habría dos meses de suspensión automática de la ejecución, lo que no se prevé en nuestro ordenamiento jurídico. Además, de ser este el criterio correcto, lo que no es así, carecería de sentido la posibilidad de adoptar medidas cautelares provisionalísimas, sin audiencia de la Administración demandada, prevista en el artículo 135 de la Ley 29/1998...» (40).

En un sentido parecido, en su Sentencia de 19 de diciembre de 2006, elTribunal Supremo ha manifestado que

"...la aceptación incondicionada y sin matiz alguno de la tesis de que la solicitud de suspensión en vía jurisdiccional conlleva, automáticamente, el desapoderamiento absoluto de la Administración para ejecutar sus propios actos, comportaría, con toda probabilidad, la quiebra del principio constitucional de eficacia...

[...]

Por ello, cuando se solicite la suspensión del acto impugnado en vía jurisdiccional, mientras no recaiga resolución en la pieza cautelar incoada al efecto, la Administración sólo podrá realizar actuaciones tendentes a la ejecución de aquél que no comprometan definitivamente, de manera irreversible, la decisión judicial que pudiera dictarse al respecto, ni constituyan obstáculos de entidad relevante para su materialización. Así lo exigen también el deber de lealtad procesal de las par-

(40) STS de 9 de febrero de 2010, recurso n. ${ }^{\circ} 2431 / 2007$. 
tes, anudado al principio de buena fe, y el respeto al reparto de poderes establecido en la Constitución» (41).

En mi opinión, lo dicho en estas dos últimas sentencias está en contradicción, en primer lugar, con la propia doctrina del Tribunal Supremo, pues, tal y como aquí ha quedado expuesto, lo que el Tribunal Supremo viene sosteniendo, con base en la doctrina de la STC 78/1996, es que mientras que el órgano judicial está resolviendo la solicitud de suspensión, la Administración no puede ejecutar el acto recurrido. Pero, en segundo lugar, y lo que es más importante, está también en contradicción con la doctrina del Tribunal Constitucional que, en buena lógica, ha concluido que si, según su propia interpretación del artículo $24 \mathrm{CE}$, la tutela judicial efectiva se satisface garantizando que los órganos judiciales puedan pronunciarse sobre la ejecutividad del acto, ello conlleva que, antes de que los órganos judiciales se pronuncien sobre ello, la Administración no puede ejecutar sus actos, cuando hayan sido recurridos y solicitada su suspensión, porque, si así lo hiciera, el pronunciamiento judicial ya no podría versar nunca sobre si la ejecución inmediata del acto privaba o no a la tutela judicial de su efectividad. En tercer y último lugar, con estas afirmaciones lo que hace el Tribunal Supremo es reconducir la cuestión a un problema de periculum in mora, lo que, en mi opinión, no es acertado, puesto que, como ya he dicho, y expuse en su momento con mayor detaIle (42), toda la construcción que el Tribunal Constitucional ha hecho sobre la tutela cautelar como derecho fundamental no descansa en el hecho de que, efectivamente, se produzcan daños irreversibles, sino, en que se dé a los órganos judiciales la posibilidad de evitarlos, para lo cual éstos tienen que poder pronunciarse sobre la procedencia en Derecho de la ejecutividad inmediata de un acto administrativo cuando ha sido recurrido $y$ solicitada su suspensión, y eso es lo que, sin embargo, no podrán hacer si, en el momento de decidir sobre si el acto administrativo debe o no ejecutarse, ese acto ha sido ya ejecutado.

Por todo lo dicho, creo que el legislador tendría que haber aprovechado la ocasión de la aprobación de estas dos nuevas leyes - en tantas cosas innecesarias - para poner orden en este estado de confusión al que ha llevado una jurisprudencia que, en ocasiones, se muestra lógica y contundente $y$, en otras, ambigua y poco convincente. Lo ha hecho, sí, con las sanciones, pero solo con las sanciones, cuando, en mi opinión, tratándose de un problema que afecta a la tutela judicial efectiva, nada justifica la diferencia de trato entre una sanción y el resto de los actos ad-

(41) STS de 19 de diciembre de 2006, recurso $n .^{\circ} 3716 / 2004$.

(42) C. CHINCHILLA MARÍN “Criterios de adopción..." cit. págs. 22-26. 
ministrativos que, por otro lado, pueden ser tanto o más gravosos que una sanción.

A este propósito, conviene recordar que, a pesar de que, en el caso resuelto por la STC 78/1996(43), se trataba de una sanción, la doctrina que entonces estableció el Tribunal Constitucional no podía no ser trasladable a todos los actos administrativos porque, como argumenté en su momento (44), lo que se dijo en esa sentencia no era más que la conclusión a la que por lógica llevaba la interpretación que el propio Tribunal había hecho, hasta ese momento, sobre la cuestión de la ejecutividad del acto administrativo y el derecho fundamental a la tutela judicial efectiva, especialmente, en su Sentencia 66/1984, en la que, por primera vez, declaró que el derecho a la tutela judicial efectiva se satisface permitiendo que la ejecutividad pueda ser sometida a la decisión de un Tribunal y que éste, con la información y contradicción que resulte menester, resuelva sobre la suspensión.

Hoy en día no creo que pueda caber duda alguna sobre que la doctrina del Tribunal Constitucional es aplicable a todos los actos administrativos, pues así lo acreditan las sentencias y Autos del Tribunal Supremo que la han aplicado en relación con actos administrativos que no eran sanciones (45) y, sobre todo, el hecho de que el propio Tribunal Supremo así lo ha declarado explícitamente en su Auto de 2 de marzo de 2016 (recurso 4100/2015), diciendo que:

«...más allá del ámbito estrictamente sancionador, si la Administración ejecuta el acto administrativo impugnado durante ese período de tiempo que media desde la solicitud de las medidas a la decisión cautelar judicial, estaría el órgano administrativo resolviendo sobre la medida instada, al menos por la vía de los hechos consumados, hurtando tal competencia al órgano judicial, lo que determinaría la vulneración de la tutela judicial efectiva».

(43) También se trataba de una sanción en el caso resuelto por la STC 243/2006 que reitera esta doctrina.

(44) C. CHINCHILLA MARíN, “Criterios de adopción...» cit. págs. 27-34.

(45) Conviene recordar algo que normalmente se olvida: bastantes años antes de que el Tribunal Constitucional y el Tribunal Supremo estableciesen la doctrina que venimos exponiendo, concretamente en 1990, la Audiencia Nacional ya dijo todo eso en un importante Auto del que di noticia en mi libro La tutela cautelar en la nueva justicia administrativa (C. CHINCHILLA MARíN, op. cit. págs. $140-141$ y 162-164). En ese caso, en el que no se trataba de una sanción, la Audiencia Nacional dijo que, si el derecho a la tutela judicial efectiva se satisface - según el Tribunal Constitucional- facilitando que la ejecutividad pueda ser sometida a la decisión de los órganos judiciales, es evidente que si la Administración ejecuta sus actos mientras estos están decidiendo sobre la cuestión, "estará violando (y esteTribunal también si no lo evita) el derecho a la tutela judicial efectiva». Igualmente, no tratan sobre sanciones y aplican la doctrina de la STC 78/1996, entre otras, la Sentencia delTribunal Supremo de 19 de diciembre de 2006 y el Auto de 2 de marzo de 2016, ambos ya citados. 
Por tanto, y con ello termino, el legislador debería haber generalizado, para todos los actos administrativos, la regla que el artículo 90.3 de la LPAC ha establecido para las sanciones y, al mismo tiempo, debería haber definido los supuestos concretos en los que un interés general muy cualificado justificaría la excepción a la regla que se deriva del derecho fundamental a la tutela cautelar. Al no haberlo hecho así, el legislador ha dejado que, desde los años noventa, en los que el Tribunal Constitucional dictó la sentencia 78/1996, una cuestión tan importante como esta siga sin tener una respuesta clara e inequívoca en nuestro ordenamiento jurídico.

Trabajo recibido el 23 de noviembre de 2017

Aceptado por el Consejo de Redacción el 16 de febrero de 2018 
LABURPENA: Sektore Publikoaren Araubide Juridikoari buruzko 40/2015 Legeak arau berria sartu du zigorrak preskribitzeko epearen zenbaketaren inguruan, zigorren aurka jarritako gora jotzeko errekurtsoak administrazioaren isiltasunaren bidez ezesten diren kasuetarako. Hala, lege horren 30.3. artikuluan ezarritakoaren arabera, errekurtsoa ustez ezesten bada, errekurtso horren ebazpena emateko legez aurreikusi den epea amaitu eta hurrengo egunetik aurrera hasi behar da zenbatzen zigorra preskribitzeko epea. Preskripzioari buruzko arau berri horrek, zentzuzkoa denez, ondorioak eduki behar ditu zigorrak betearazteko araubidearen gainean, zigorra bete behar izatea baita zigorra preskribatzeko oinarria. Artikulu honetan, bi berritasun horien berri ematen da, eta kontraesan-arazoa aztertzen, Konstituzio Auzitegiak eta Auzitegi Gorenak errekurtso-bideko isiltasunaren eta isiltasun horrek zigorren preskripzioaren eta bete behar izatearen gainean dituen ondorioen - hobeto esanda, "ondorio-ezaren"- inguruan duten jurisprudentziari dagokionez.

GAKO HITZAK: Administrazio-zehapenak. Preskripzioa. Bete beharra. Administrazioaren isiltasuna. Administrazio-errekurtsoak.

RESUMEN: la Ley 40/2015, de Régimen jurídico del Sector público, ha introducido una nueva regla sobre el cómputo del plazo de prescripción de las sanciones en los casos en los que el recurso de alzada interpuesto contra las mismas se desestima por silencio administrativo. Así, a tenor de lo establecido en el artículo 30.3 de esta ley, en el caso de desestimación presunta del recurso, el plazo de prescripción de la sanción comenzará a computarse desde el día siguiente a aquel en el que finalice el plazo legalmente previsto para la resolución de dicho recurso. Esta nueva regla sobre la prescripción lógicamente tiene que producir consecuencias sobre el régimen de ejecutividad de las sanciones, pues la ejecutividad de la sanción constituye el presupuesto de la prescripción de la misma. En este artículo se da cuenta de ambas novedades y se analiza el problema de su contradicción respecto de la jurisprudencia - del Tribunal constitucional y del Tribunal Supremo- sobre el silencio en vía de recurso y sus efectos (más bien, sus «no efectos») sobre la prescripción y la ejecutividad de las sanciones.

PALABRAS CLAVE: Sanciones administrativas. Prescripción. Ejecutividad. Silencio administrativo. Recursos administrativos.

ABSTRACT: The Act 40/2015 of the legal regime of the Public Sector has introduced a new rule on the calculation of the limitation period to be applied to sanctions in cases where hierarchichal appeal filed against them had been rejected by administrative silence. Thus, within the meaning of section 30.3 of this Act, in case of implied rejection of the appeal, the calculation of the limitation period of the sanction shall begin from the day following the deadline legally established to resolve that appeal. This new rule about the limitation period has logically to have consequences over the enforceability of sanctions, since enforceability of the sanction as such is a prerequisite for the limitation period of it. This article deals with both novelties and analyzes the problem of their contradiction with the case 
law - by the Constitutional Court and the Supreme Court- regarding the silence within the appeal and its effects (or rather lack of effects) about the limitation period and enforceability of sanctions.

KEYWORDS: Administrative sanctions. Limitation period. Enforceability. Administrative silence. Administrative appeals. 